Original Research Paper

\title{
Cash Holdings, Use of Debt and Dividend Structure of Family Firms
}

\author{
${ }^{1}$ Elena Smirnova, ${ }^{2}$ Sirousse Tabriztchi and ${ }^{3}$ Cary Lange \\ ${ }^{1,2}$ Department of Management, Marketing and Finance, School of Business, \\ ${ }^{3}$ Department of Accounting, School of Business, \\ State University of New York, College at Old Westbury, Old Westbury, New York, USA
}

Article history

Received: 19-03-2015

Revised: $15-04-2015$

Accepted: 20-04-2015

Corresponding Author:

Elena Smirnova

Department of Management, Marketing and Finance, School of

Business, SUNY College at Old

Westbury, Old Westbury, NY,

USA

Email: smirnovae@oldwestbury.edu

\begin{abstract}
In this study we examine the relation between firm's financial structure and family ownership. We develop a theoretical model of the precautionary cash holdings. Our empirical results show that the fraction of a company's shares that are held by the founding family members or their descendants influences the use of cash and equivalents, dividend policy and debt structure of a firm. Our results are robust to different estimation methods and alternative model specifications. We find that family firms tend to rely less on long-term debt financing, pay fewer dividends and carry higher precautionary cash balances.
\end{abstract}

Keywords: Family Firms, Cash Holdings, Financial Structure

\section{Introduction}

Family firms present an interesting platform for academic research. Prior research has, in large part, provided evidence suggesting that the presence of founding family members as stakeholders and in management is an efficient and profitable ownership structure. Extant literature has found evidence consistent with family firms creating value when the founder serves as CEO or Chairman, that family firms perform better than their non-family counterparts as measured by both accounting and market measures, enjoy a lower cost of debt, have better earnings quality and lower abnormal earnings, among other traits.

Agency theory establishes that, in a relationship where one party (the principal), has engaged another party (the agent), to perform some service or function on his behalf, conflicts can arise because of the differing interests of the parties involved in the contract (Jensen and Meckling, 1976). One of the characteristics of publicly traded corporations is the separation of ownership and control that can give rise to these agency conflicts (Jensen and Meckling, 1976; Demsetz and Lehn, 1985; Shleifer and Vishny, 1986). There are two competing theories within the agency structure on the effect of founding family ownership on the demand and supply of earnings quality that have been the basis of academic research into the family firm structure: The entrenchment effect and the alignment effect. The entrenchment effect predicts that concentrated shareholders, in this case family shareholders, may try to expropriate wealth from other shareholders. In contrast to the entrenchment effect, the alignment effect predicts that, as ownership increases, managers' incentives will align with those of more atomistic shareholders.

Founding family ownership presents a special case of concentrated ownership. Founding families tend to have poorly diversified portfolios (with the majority of the family wealth concentrated in the family firm), have longer term investment horizons than the typical manager (they view their stake in the firm as a legacy to be passed to future generations, as opposed to wealth to be spent in their lifetime) and often control senior management positions. As such, founding families, as influential shareholders, are in a position to exert substantial control and influence over the firm.

The application of agency theory to family firms raises the question of what will happen as the firms mature and the family members reduce their ownership stakes. Will the family owners behave more like non-family firms and invest in riskier projects using debt financing or will they maintain higher levels of cash to mitigate this risk? To answer this question our paper uses a theoretical model of precautionary cash balances to test whether family firms maintain higher levels of cash as a measure to reduce risk, thus requiring lower debt financing. In addition, the model tests whether this is accomplished (at least in part) by dividend reduction policies. 
The empirical investigation of the theoretical model shows that family firms do indeed keep higher precautionary cash balances, pay lower dividends and rely less on long-term debt for their financing needs than non-family firms. We make use of a unique set of handcollected data of firms in the Standard and Poor's 500 index during the period 1998-2007. Family ownership information was obtained using firm histories posted on company websites, Hoovers and other publicly available sources. Family stock holdings and management positions were obtained by combing annual reports, proxy statements and other stock ownership filings available on the SEC's EDGAR database.

This paper contributes to the body of work on family firms by providing additional evidence suggesting that the family ownership structure mitigates the agency conflicts that can arise when there is a separation of ownership and management. The results suggest that there is an alignment of managers' incentives with the incentives of owners with a more concentrated ownership stake and management structure.

\section{Related Literature}

The concept of valuation of family firms was addressed by Jensen and Meckling (1976) through their theoretical model of increased agency costs when company ownership becomes dispersed. They argued that a company with concentrated ownership, which is true for family forms of business, will be valued higher than a firm with broadly distributed ownership. Fama and Jensen (1983) provide explanation for why family firms are more conservative in their decision making than non-family firms and discuss the mutual monitoring by managers and employees. This stream of research is followed by Anderson and Reeb (2003) and Villalonga and Amit (2006), who contributed to the family literature by studying publicly-traded family firms. For example Anderson and Reeb (2003) suggest that family firms generate a value premium through lower agency costs, which might stem from lower leverage and a lower cost of debt of family-owned firms. Anderson and Reeb (2003) also show that market performance is improved by having a founder or an outsider serve as a CEO. Additionally, Villalonga and Amit (2006) show that family ownership, control and management positively affect firm value through expertise brought in by the founders. However, family firms may have negative as well as positive implications for corporate governance. For example, Morck et al. (1988) using a sample of Fortune 500 companies, show that Tobin's Q initially rises sharply as the managerial ownership goes from zero to $5 \%$ level, it decreases as ownership reaches $20 \%$ and goes up slowly for large ownership stakes above $25 \%$. Entrenchment of family management might not imply inefficiency but rather an owner-manager quest for a strategy that balances profits and private benefits.
Martínez et al. (2007) study the impact of family ownership on firm performance by using a set of data on Chilean firms. They find that from a sample of 175 firms listed on the Chilean stock market, the group of 100 family-controlled firms performs significantly better than the group of 75 nonfamily companies over the 10year period under study (1995-2004). Three distinct measures of performance-ROA, ROE and a proxy of Tobin's Q-were employed to test the differences of means between the two groups of firms. These results are in line with their multiple regression models.

An array of studies focuses on the use of cash holdings by companies as means to mitigate agency conflicts. Brockman et al. (2008) show that cash holdings are valued $47 \%$ higher in family firms since they have a better alignment of interests between founding families and other shareholders and enhanced monitoring by founding families. They also find that family firms hold higher percentage of cash relative to total assets and the results are mainly driven by firms with founder-CEOs.

Belenzon and Zarutskie (2012) study the performance of a large sample of new family- owned firms in Great Britain, France, Germany and Italy. They find that these firms have higher returns on assets, wider profit margins and greater survival rates than new nonfamily-owned firms. The authors relate that result to the managers of these companies holding higher ratio of cash and lower percentage of equity to total assets.

So far, we discussed prior literature that relates family ownership to firm performance and financial structure. Another strand of research investigates the use of cash and equivalents in a general firm setting. For example, Mikkelson and Partch (2003) test whether the cash prevents underinvestment in positive NPV projects by well-intentioned managers as predicted by Myers (1977; 1984) and Myers and Majluf (1984), or whether it facilitates overinvestment in negative NPV projects by entrenched managers (See Easterbrook (1984), Jensen (1986) and Myers and Rajan (1998)). Jensen (1986) conjectures that managers hold excess cash for their own self interests, allowing them flexibility to spend cash to pursue their own objectives. When managers fund projects from cash holdings, they avoid the discipline of raising funds externally in the capital markets, which may allow them to undertake projects the capital markets would not be willing to finance. Mikkelson and Partch (2003) obtain managerial control rights data for over 5000 firms from 31 countries and construct proxies that measure the degree of managerial control and entrenchment. They find moderate evidence that controlling managers hold more cash and that this relation is stronger when country-level external shareholder protection is weak. 
Small firms may hold more cash not only because doing so allows them to avoid the higher issuance costs they incur when raising external funds, but also because they are more likely to face borrowing constraints (Whited, 1992; Brown and Petersen, 2011). Kim et al. (1998) find that cash holdings are inversely related to debt ratios while Opler et al. (1999) argue that firms with greater likelihood of financial distress should hold more cash. Baskin (1987) finds that the cost of funds used to invest in liquid assets increases as a firm's debt ratio increases and John (1993) argues that firms use borrowing as a substitute for maintaining stocks of liquid assets. Guney et al. (2007) contend that debt acts as a substitute for cash holdings at low levels of leverage. Using a large sample of firms from France, Germany, Japan, the United Kingdom and the United States, they find a negative relationship between cash holdings and leverage at low levels of leverage. The relation turns positive at high levels of debt as the cost of financial distress increases.

Firms with more abundant investment opportunities and greater uncertainty in their cash flows may hold more cash to ensure being able to fund investments when internally generated cash flow is low and raising external funds is too costly. The opportunity costs of having to forego future investments when liquid funds are low or when external capital is too expensive is higher for those firms with more valuable investment opportunities. Kim et al. (1998) and Opler et al. (1999) incorporate proxies for the extent of investment opportunities and the variability of a firm's cash flows into their optimal tradeoff models. Kim et al. (1998) use a logarithmic growth rate in the index of leading economic indicators as a proxy for the extent of profitable investment opportunities, while Opler et al. (1999) use market-to-book ratios. Both studies find that a firm's cash holdings increase with the level of investment opportunities and uncertainty in future cash flows.

Baskin (1987) argues that firms with abundant investment opportunities also have an incentive to hold more cash to maintain their competitive positions. Holding excess cash may deter competition in a firm's product markets. For example, Froot (1993) cites Intel's use of excess cash holdings to maintain its competitive position in the early 1990s. Information asymmetries for firms with abundant investment opportunities may also affect their level of cash holdings. Because the information asymmetry between managers and outside investors may cause investors to discount new securities issued by firms, firms that need external funds to finance a positive-NPV project may simply choose to forego projects when the discounts are too severe. Opler et al. (1999) suggest that firms with high information asymmetries may therefore choose to hold higher levels of cash. Specifically, they hypothesize that firms with higher R\&D expenses will hold more cash, as these expenses would likely involve important information asymmetries.

Agency costs of managerial discretion may also affect a firm's cash holdings. Stulz (1990) argues that this agency problem is more acute for low versus high market-to-book firms. Increasing the level of managerial ownership may reduce the agency costs of managerial discretion by aligning the interests of managers and shareholders. Based on these arguments, Opler et al. (1999) suggest that a firm's cash holdings should be inversely related to market-to-book ratios and managerial ownership.

Other factors may also affect a firm's cash holdings. Because firms can conserve cash by reducing dividends or raise cash by selling assets, Opler et al. (1999) suggest that dividend-paying firms or those that can easily sell assets hold lower levels of cash. Andrei and Vishny (1992) find that companies with firm-specific assets cannot easily or quickly sell their assets to raise cash. Opler et al. (1999) argue that firms with multiple product lines and low inventory levels relative to sales have shorter cash conversion cycles and therefore hold less cash. They argue that firms using derivatives can reduce their cash holdings by coordinating risk management and cash management activities. Kim et al. (1998) find that a firm's level of cash holdings is inversely related to a return spread, measured as the difference in the return on a firm's assets and the return on Treasury bills. Their evidence also shows that firms with lower returns on their physical assets relative to the return on liquid assets tend to carry larger stocks of liquid assets. Kim et al. (1998) find support for a tradeoff model where a firm's optimal level of cash increases with the cost of external financing, volatility of cash flows and return on future investment opportunities and decreases with the difference in returns between physical and liquid assets. Opler et al. (1999) also find support for a tradeoff model where small firms with strong growth opportunities and riskier cash flows hold more cash and large firms with strong credit ratings hold less.

This paper contributes to the current family business research in two distinct ways. First, we introduce a theoretical model which explains the financial strategies employed by the family firms. Second, we test the corollaries of the model empirically. Specifically, our results show that the family firms have higher cash holdings, less leveraged capital structures and pay fewer dividends. The next section introduces theoretical model of precautionary cash balances. 


\section{Theoretical Framework}

This section provides a theoretical model of precautionary cash balances and dividend policy in family firms. The model proposed in this section has two parts. The first part is dynamic; it shows that the pure profits and return on the investment of a family business decrease over time. As the rate of return on family investment approaches the required rate of return given the firm's market risk, measured by the CAPM beta, the family founders reduce their percentage ownership. The family owners sell their shares, declare more dividends and finance new investment by greater borrowing. The second part of the model shows that the increased leverage of a family firm leads to keeping additional precautionary cash and lower dividends.

A study closely related to the current research is by Kim et al. (1998) who model firm's optimal cash holdings and investment policy. There are, however, important differences between our paper and theirs. First, Kim et al. (1998) do not generate the precautionary motive for cash holdings. They assume that current investments and cash holdings are substitutes for future liquidity needs. Consequently, the optimal decisions on current investments and cash holdings are decided by a static trade-off between current investments and cash holdings. In other words, their model does not consider the intertemporal trade-off between current and future investments. It predicts that only a financially unconstrained firm with an extra cash endowment (meaning that the marginal return on current investments is lower than the risk free rate) holds a positive amount of cash, while a financially constrained firm holds zero cash. Consequently, the motive for a firm to hold positive cash is due to an extra cash endowment and not as a precautionary consideration, as predicted in our research.

\section{Optimal Ownership Percentage}

Let us denote the beginning value of innovative monopolistic family enterprise by $V_{0}$. This value is assumed to grow at a decreasing rate, due to rising competition. The increase factor is exemplified by $\mathrm{e}^{\sqrt{\mathrm{t}}}$. Further, it is assumed that the family-owner's opportunity cost of capital is $i$, the required rate of return for a public company with similar market risk (beta), under the Capital Asset Pricing Model.

The family-owner's wealth maximizing objective function is assumed to be:

$\operatorname{Max} V_{t}=V_{0} e^{V_{t}} e^{-i t}$

The maximum firm value is achieved if:

$$
\frac{d V_{t}}{d t}=0.5 t^{0.5}-i=0 \text { or } 0.5 t^{0.5}=i \text { and } d^{2} V_{t}=0.25 t^{-25}<0
$$

Consequently, when the rate of growth of firm $\left(0.5 t^{0.5}\right)$ equals the cost of capital $(i)$ the firm has reached the state financial maturity. Up to the point of maturity, the family business owners are heavily invested in their company. They finance the operations by using less leverage than non-family businesses. This strategy is feasible, because the substantial cash inflows from pure profits are reinvested to earn abnormal returns and make long-term borrowing less necessary. As the point of financial maturity approaches, two sets of opportunities are open to the owners: Declare dividend and diversify through investment in efficient market portfolio or invest in risk reducing projects that lower the discount rate below their return. The point of financial maturity is associated with greater emphasis on investments that reduce the cost of capital and make additional net investment possible.

The model shows that when condition in Equation 2 is satisfied, the family-owners keep relatively larger safety stock of cash (precautionary motive), maintain lower leverage ratios (financial risks), invest more in hedging and insurance and thereby decrease their company specific risk premium and shift the discount rate down to increase their firm value.

Portfolio holders of non-family owned businesses can reduce their unsystematic risk by investing in market portfolio, risk free assets or engage in company specific risk reduction, if they can exert some influence. The possibility and convenience of a non-involved and passive diversification provides less economic incentive to nonfamily-owners to reduce their company specific risks than the fully committed single-asset holding family-owner. Consequently, we predict that the family firms have lower risk assets holdings and less leveraged capital structures.

\section{Family Ownership and Precautionary Cash Balances}

In the standard two asset portfolio theory with one risk free asset (Cash equivalent) and one risky asset (Stock) the portfolio return is:

$$
E k_{p}=w k_{r f}+(1-w) E k_{r}
$$

where, $\mathrm{E} k_{p}, k_{r f}$ and $E k_{r}$ are the expected rate of return on the portfolio, risk free asset and the expected return on a risky asset, respectively.

In the standard model it is assumed that the weight of risk free asset ( $w$, or portion of cash investment in our case) does not affect the standard deviation of the risky investment. The portfolio risk $\left(\sigma_{\mathrm{p}}\right)$ is a linear function of the standard deviation of the risky asset $\left(\sigma_{\mathrm{r}}\right)$ :

$$
\sigma_{p}=(1-w) \sigma_{r}
$$

In a family-owned firm, the firm's market and idiosyncratic risk is higher. By keeping more cash and 
equivalents a family firm owner can reduce the volatility of cash flows and as a result signal reduced risk to investors, lenders, suppliers and customers (This signaling is important since the banks providing a line of credit often insist on keeping compensating balances).

The relationship of $w$ and the standard deviation of $k_{r}$ is modeled as follows:

$$
\left\{\begin{array}{l}
\frac{d \sigma}{d w} \leq 0 \text { for } w \leq w^{*} \\
\frac{d \sigma}{d w}>0 \text { for } w>w^{*}
\end{array}\right.
$$

The inequalities presented in Equation 5 show that there is $w^{*}$ at which $\sigma$ is at minimum. Keeping additional cash beyond the optimal level leads to poorer return and lower market valuation. In order to make the relationship explicit we assume the relationship between $w$ and $\sigma_{\mathrm{r}}$ is quadratic.

$\sigma=\sigma_{0}+a\left(w-w^{*}\right)^{2}$

The standard deviation of portfolio is defined in Equation 4. On substituting from Equation 6 into Equation 4 we obtain:

$\sigma_{p}=(1-w)\left(\sigma_{0}+a\left(w-w^{*}\right)^{2}\right)$

Solving Equation 8 for each specified $\sigma_{\mathrm{p}}$ we can find the related portfolio weight of the risk free asset (cash). The relationship of $\sigma_{\mathrm{p}}$ and $w$ is presented in the following Fig. 1, where it is compared to the line that represents the condition in which standard deviation of risky asset $\left(\sigma_{\mathrm{r}}\right)$ is not related to $w$.

Using Equation 3 and 8 we can obtain the feasible risk - return trade off curve presented in Fig. 2.

If we assume a risk free rate of $2 \%$ and market portfolio rate of return of $12 \%$, (To facilitate comparison market rate of return is set equal to the return on the firm's risky asset) the risk return straight line shows the capital market line and the concave curve shows the feasible set for the company. The internal investment curve above depicts first order stochastic dominance over capital market line. This means that even in the absence of corporate taxes it is advantageous to keep the precautionary cash in the firm and invest the funds in the firm, rather than declare dividend and invest externally.

The above analysis shows that as family firms approach maturity and the owners reduce their holdings to a small amount, the risks of debt-financed investment are reduced by slashing dividends and keeping more cash. The next section shows empirically how debt, cash and dividends differ for publicly traded family versus non-family firms.

\section{Sample Description and Empirical Design}

Theoretical model developed in section 2 conjectures that family firms would hold more cash than non-family counterparts as a precautionary item. This section tests the corollaries of the model empirically in regards to cash and equivalents, dividends and long-term debt.

The firms used in our study are publicly traded companies that are included in the S\&P500 index during 1998-2007. The 125 financial companies and utilities are excluded due to different regulatory disclosures. We split the remaining sample of 375 companies into two groups-firms with zero family ownership and firms where the founding individuals or their descendants own some company shares. We define family ownership as any positive percentage of stock ownership by either founding individuals or their descendants. The result is a sample of 144 family-owned and 231 non-family owned firms, which is reduced further by availability of CRSP and Compustat data for the years 1998-2007. Our sample size is 1700 firm-year observations for non-family owned firms and 1020 firm-year observations for family owned firms. The sample characteristics are reported in Table 1. Difference in means is calculated as the average for nonfamily firm minus the average of the family owned firm.

Table 1 show that family-owned firms have less long-term debt on average than non-family owned firms based on statistically significant differences in means. In addition, family-owned companies in our sample pay fewer dividends than non-family firms and generally keep greater cash and equivalents on their books.

The empirical model design is consistent with precautionary cash consideration developed in previous section. The intertemporal trade-off between current and future investments triggers the optimal family ownership percentage, when the company foregoes dividend and keeps cash internally, at the same time decreasing its reliance on long-term debt.

Previous research related to the current choice of explanatory variables includes, for example, Park and Son (2009), who assess the relationship between corporate governance and equity financing by using a sample of active firms on Compustat. They employ return on assets to measure firms' profitability and financial condition; they also include market-to-book value of firm's equity as a proxy for growth opportunities. Villalonga and Amit (2009) utilize Tobin's Q as a dependent variable to gauge the effect of dual class shares and corporate control mechanisms on value of family-owned firms. 
Table 1. Sample descriptive statistics

\begin{tabular}{|c|c|c|c|c|c|c|c|c|}
\hline & \multicolumn{3}{|c|}{ Family owned firms (1) } & \multicolumn{3}{|c|}{ Non-family owned firms (2) } & \multicolumn{2}{|c|}{ Difference (2)-(1) } \\
\hline & $\begin{array}{l}\text { Standard } \\
\text { deviation }\end{array}$ & Median & Mean & $\begin{array}{l}\text { Standard } \\
\text { Deviation }\end{array}$ & Median & Mean & Means & $\begin{array}{l}\mathrm{t}- \\
\text { statistics }\end{array}$ \\
\hline Family ownership & 0.12 & 0.04 & 0.09 & $\mathrm{n} / \mathrm{a}$ & $\mathrm{n} / \mathrm{a}$ & $\mathrm{n} / \mathrm{a}$ & $\mathrm{n} / \mathrm{a}$ & $\mathrm{n} / \mathrm{a}$ \\
\hline Total assets & 31601.28 & 6052.94 & 14540.20 & 60000.19 & 8340.84 & 22212.44 & 7672.23 & 4.67 \\
\hline Common equity & 8831.25 & 2472.55 & 5471.02 & 13191.55 & 2767.92 & 6780.71 & 1309.68 & 3.40 \\
\hline Cash & 2701.81 & 414.05 & 1124.46 & 2768.84 & 364.57 & 1109.81 & -14.65 & -0.16 \\
\hline Cash and Short-Term Investments & 5352.75 & 604.54 & 1942.72 & 3891.34 & 468.53 & 1641.01 & -301.71 & -1.88 \\
\hline Common Shares Outstanding & 1209.93 & 275.89 & 639.96 & 1194.88 & 243.50 & 603.55 & -36.41 & -0.88 \\
\hline Total Long-Term Debt (\$ mln) & 10953.01 & 809.15 & 3017.16 & 18963.52 & 1612.80 & 4813.93 & 1796.77 & 3.38 \\
\hline Short term debt (notes) & 5996.49 & 400.28 & 1731.58 & 16029.72 & 895.03 & 3215.55 & 1483.96 & 3.58 \\
\hline Common Dividends & 1223.25 & 54.54 & 219.45 & 1298.16 & 109.90 & 479.66 & 260.21 & 6.02 \\
\hline Dividends-Preferred & 9.38 & 0.00 & 1.50 & 9.63 & 0.00 & 2.03 & 0.53 & 1.62 \\
\hline Dividends total & 1223.44 & 55.01 & 220.95 & 1298.45 & 111.00 & 481.71 & 260.76 & 6.03 \\
\hline Earnings Before Interest and Taxes (\$mln) & 2535.92 & 645.03 & 1403.96 & 4889.75 & 844.55 & 2182.94 & 778.98 & 5.83 \\
\hline Earnings Before Interest & 3638.63 & 895.83 & 2055.26 & 6311.17 & 1255.30 & 2980.68 & 925.42 & 5.24 \\
\hline Earnings Per Share (Diluted) & 2.49 & 1.41 & 1.57 & 3.68 & 1.87 & 1.94 & 0.38 & 3.49 \\
\hline Earnings Per Share (Basic) & 2.54 & 1.45 & 1.61 & 3.71 & 1.90 & 1.99 & 0.37 & 3.42 \\
\hline Goodwill & 3119.38 & 573.00 & 1616.87 & 6820.51 & 974.53 & 2934.96 & 1318.08 & 7.25 \\
\hline Inventories & 3013.96 & 479.28 & 1331.03 & 2708.43 & 554.00 & 1451.71 & 120.68 & 1.23 \\
\hline Short-Term Investments & 3458.09 & 12.67 & 861.84 & 1924.34 & 0.00 & 461.89 & -399.95 & -4.17 \\
\hline Current Liabilities & 5236.73 & 1462.10 & 2932.32 & 6150.21 & 1827.60 & 3915.73 & 983.41 & 5.02 \\
\hline Total Liabilities & 27701.79 & 3201.07 & 8988.11 & 50249.44 & 5063.85 & 15211.85 & 6223.74 & 4.47 \\
\hline Net income & 2271.21 & 366.89 & 731.02 & 3668.97 & 414.65 & 1138.11 & 407.09 & 3.89 \\
\hline Operating Activities Net Cash Flow & 3264.31 & 691.16 & 1673.79 & 4920.47 & 808.60 & 2162.63 & 488.84 & 3.42 \\
\hline Earnings Per Share from Operations & 1.91 & 1.55 & 1.89 & 2.07 & 2.09 & 2.39 & 0.50 & 7.34 \\
\hline Property, Plant and Equipment & 15052.00 & 2332.59 & 7266.93 & 25662.51 & 3897.62 & 11149.54 & 3882.61 & 5.38 \\
\hline Retained Earnings & 7338.40 & 1697.24 & 2971.54 & 16281.14 & 2043.30 & 5607.33 & 2635.79 & 6.09 \\
\hline Revenue-Total & 30871.50 & 5832.49 & 14405.77 & 31113.82 & 7481.98 & 16167.42 & 1761.65 & 1.66 \\
\hline Sales/Turnover (Net) & 30871.50 & 5832.49 & 14405.77 & 31113.82 & 7481.98 & 16167.42 & 1761.65 & 1.66 \\
\hline Stockholders' Equity (\$ mln) & 8837.36 & 2482.44 & 5491.31 & 13190.56 & 2777.95 & 6806.17 & 1314.86 & 3.42 \\
\hline Working Capital (Balance Sheet) & 3862.34 & 787.94 & 1526.66 & 2952.06 & 578.71 & 1190.87 & -335.79 & -2.85 \\
\hline Dividends per Share (calendar) & 0.61 & 0.23 & 0.42 & 1.31 & 0.56 & 0.69 & 0.26 & 7.56 \\
\hline Market value $(\$ \mathrm{mln})$ & 44648.66 & 8880.16 & 22282.77 & 51523.59 & 9035.07 & 25527.53 & 3244.76 & 1.96 \\
\hline Closing price (annual) & 28.63 & 35.62 & 40.57 & 23.51 & 39.82 & 42.95 & 2.38 & 2.65 \\
\hline Sample size (firm-years) & 1020.00 & & & 1700.00 & & & & \\
\hline
\end{tabular}

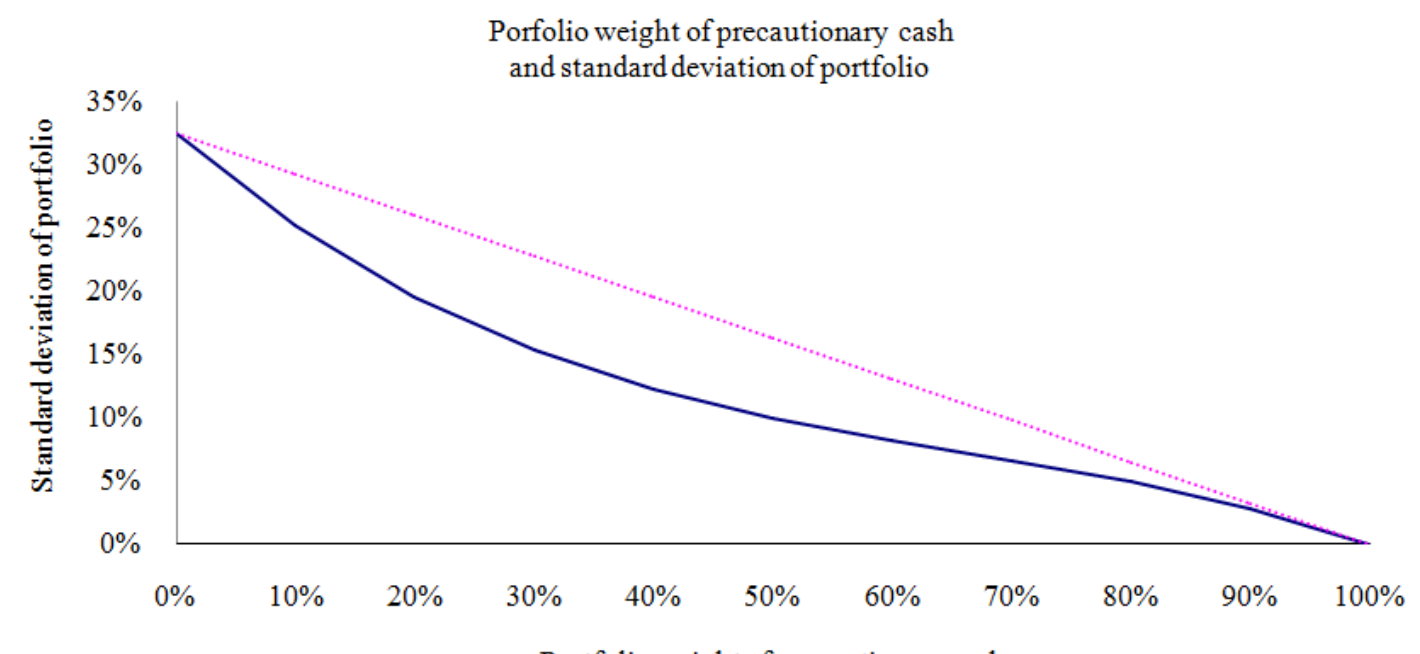

Portfolio weight of precautionary cash

Fig. 1. Portion of risk-free asset (cash) and standard deviation of portfolio

Belenzon and Zarutskie (2012) use a sample of private Western European companies and show that family-owned firms have higher profit margins, returns on assets and survival rates compared to non-family owned firms. They also examine firms with marital ties and find that married owners facilitate greater reserves of cash, rely less on external debt and invest more conservatively than their non-married counterparts. 


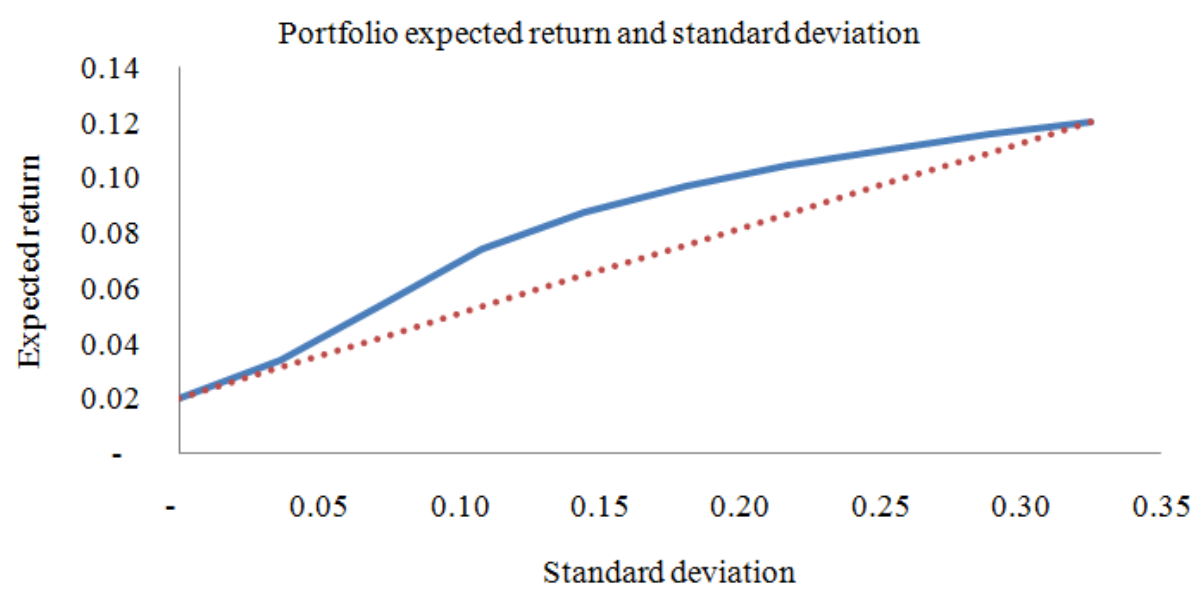

Fig. 2. Portfolio expected return and standard deviation

Table 2. Impact of family ownership on leverage and liquidity. The table reports results of OLS regression of long-term debt scaled by total assets and cash and equivalents scaled by total assets on family indicator and natural logarithm of sales. Regression includes industry indicators

\begin{tabular}{lll}
\hline & Long-term debt/ Total Assets (1) & Cash/ Total Assets (2) \\
\hline Intercept & $0.159^{* * *}$ & $0.442^{* * *}$ \\
Family Indicator & $-0.039^{* * *}$ & $0.044^{* * *}$ \\
Ln(Sales) & $0.006^{* *}$ & $-0.039^{* * *}$ \\
Industry indicators & Yes & Yes \\
R-square & 0.079 & 0.178 \\
Sample size & 2720 & 2720 \\
\hline
\end{tabular}

$*, * *, * * *$ indicates statistical significance at 15,10 and $5 \%$ levels

There are two differing interpretations of Tobin's Q. In one interpretation it is conceived as a measure of over and undervaluation of the firm in relation to the replacement cost and in the second it is treated as a measure of intangible assets and goodwill created by family and non-family businesses over and above the replacement cost. The test results for family-owned businesses that show lower costs (CEO compensation) and risks (higher relative cash and lower relative longterm debt) are consistent with Tobin's Q as a measure of increased firm value and a proxy for lower agency costs.

Additionally, Dybvig and Warachka (2010) refer to the problem of endogeneity of Tobin's Q, demonstrating that underinvestment lowers firm performance while increasing Tobin's Q. We address that concern in a later section by implementing a two-stage least squares model with Everyday Price Index (EPI) as an instrumental variable. Everyday Price Index (EPI) is developed and computed monthly by the American Institute of Economic Research (AIER). The methodology makes it appropriate for use in a family-firm context. As we explain further in section 4 , it is constructed by tracking everyday living expenses rather than core inflation items.

\section{Leverage and Liquidity of Family-Owned Firms}

So far, we have found some preliminary evidence that family firms have higher cash and equivalents and less long-term debt (Table 1). Belenzon and Zarutskie (2012) find similar results in terms of ability of family firms to commit to keep cash within a firm for future investment and use less leverage due to better monitoring mechanisms than outside debt. In this section we test those findings further by running various model specifications that control for firm characteristics:

Long-term debt $=\beta_{0}+\beta_{1}^{*}$ Family Indicator $+\beta_{2} *$
Ln(Sales)
Cash and equivalents $=\beta_{0}+\beta_{1}^{*}$ Family Indicator $+\beta_{2}$
$* \operatorname{Ln}($ Sales $)$

Table 2 reports the regression results. Each equation includes a set of industry indicators.

Family-owned companies appear to have less longterm debt and higher cash and equivalents as was previously shown in Table 1 . We interpret this result as evidence of better alignment of shareholder interests with management goals in family firms. Less reliance on longterm debt and higher cash holdings is made possible by decreased need to constrain management in their investment decisions. Family firms rely on other monitoring mechanisms such as reputation and family ties. 
Next, we include Return on Assets and Tobin's Q as control variables for firm' profitability and growth prospects:

Long-term debt $=\beta_{0}+\beta_{1} *$ Family Indicator $+\beta_{2} *$ ROA $+\beta_{3} *$ Tobin's $Q$

Cash and equivalents $=\beta_{0}+\beta_{1}^{*}$ Family Indicator $+\beta_{2} *$ $\mathrm{ROA}+\beta_{3} *$ Tobin's $Q$

Specifications (1) and (2) in Table 3 report the regression results. Each equation includes a set of eight industry indicators.

Tobin's Q is computed as market value of equity plus book value of long-term debt, all divided by book value of total assets and Return on Assets are computed as net income over total assets. These two variables control for market value and profitability of family-owned companies since previous research have shown that those two factors are significantly different in family businesses (See literature review section for discussion of previous studies).

As we can see from Table 3 family indicator is statistically significant and negative in the Long-term Debt regression, inferring that family-owned firms rely on less long-term debt in their financing decisions than non-family firms. The Cash regression shows that family indicator is positive and statistically significant, meaning that family-owned firms are able to hold higher cash and short-term investments balances on their books than nonfamily companies.

Next, we test the model corollary on the effect of dividends on the family-firm investment strategies. When a family firm reaches a steady state, i.e., its growth rate becomes equal to the discount rate, the owners can either declare a dividend and use it to diversify through a market portfolio, or they can invest in low risk projects thus reducing the discount rate below their rate of return. The next regression equation tests whether the model prediction holds and the dividends paid are lower for family owned firms than for nonfamily businesses:

\section{Dividends $=\beta_{0}+\beta_{1} *$ Family Indicator $+\beta_{2} * R O A+\beta_{3}$ * Tobin's $Q$}

Specification (3) of Table 3 reports the results of the above regression. As predicted by the theoretical model, the coefficient of the family indicator is negative and statistically significant, meaning that family owned companies in our sample pay fewer dividends than non-family owned businesses. We can conclude that family firms revert to financial strategies other than paying the dividends to achieve an optimal point of family ownership.

\section{Robustness Check}

We incorporate two additional exogenous control variables, including the Everyday Price Index, developed by the American Institute of Economic Research and the nominal interest rate on a one-year Treasury note. The choice of the variables is motivated by the fact that EPI by the nature of its construction measures the everyday cost of consumer basket as opposed to the CPI which excludes items such as gasoline and food in order to measure core inflation. Nominal interest rate has an impact on the cost of borrowing and the levels of debt that companies can afford.

The purpose of the AIER Everyday Price Index (EPI) is to measure the changes in prices of goods and services people buy frequently that have prices that are not contractually fixed. These are items such as food, gasoline, utilities, personal care products, child care expenses. Fluctuations in such prices reflect the pricing risk (i.e., unexpected and unavoidable volatility) consumers face in connection with purchases they cannot easily adjust from one month to the next. The EPI is constructed from a subset of categories of consumer expenditures, taken from the full list of categories that the Bureau of Labor Statistics uses to construct the Consumer Price Index (CPI).

Each of the components included in the EPI is weighted by the expenditure share devoted to it. These weights are exactly equal to the weights used in the CPI and they are derived from the Consumer Expenditure Survey conducted by BLS. This means that the EPI assumes the same consumer expenditure patterns the CPI does. The weights are adjusted annually to reflect changing expenditure patterns.

The second control variable that we include impacts the cost of capital for a company. One year Treasury note annual rate is taken from the Federal Reserve database (We download the annual nominal one-year Treasury note from www.federalreserve.gov/releases/H15). We combine the control variables in the following regression:

Long-term debt $=\beta_{0}+\beta_{1} *$ Family Indicator $+\beta_{2} * R O A$ $+\beta_{3} * E P I+\beta_{4} *$ Rate

Cash and equivalents $=\beta_{0}+\beta_{1} *$ Family Indicator $+\beta_{2}$

$*$ ROA $+\beta_{3} * E P I+\beta_{4} *$ Rate

Dividends $=\beta_{0}+\beta_{1}^{*}$ Family Indicator $+\beta_{2} * R O A+\beta_{3}$ $* E P I+\beta_{4} *$ Rate

The results are presented in Table 4 .

All the previous results remain valid after inclusion of the control factors. Family firms in our sample are able to borrow less long term debt, accumulate higher cash and equivalents and pay fewer dividends than nonfamily companies in the same sample. 
Table 3. Impact of family ownership on leverage and liquidity corrected for firm characteristics. The table reports results of OLS regression of long-term debt scaled by total assets (column 1), cash and equivalents scaled by total assets (column 2) and dividends scaled by total assets (column 3) on family indicator, return on assets and Tobin's Q. Regression includes industry indicators

\begin{tabular}{llll}
\hline & $\begin{array}{l}\text { Long-term debt/ } \\
\text { Total Assets (1) }\end{array}$ & $\begin{array}{l}\text { Cash/ Total Assets } \\
\text { Total Assets (2) }\end{array}$ & $\begin{array}{c}\text { Dividends/ Total Assets } \\
(3)\end{array}$ \\
\hline Intercept & $0.231^{* * *}$ & $0.068^{* *}$ & $0.008^{* * *}$ \\
Family Indicator & $-0.034^{* * *}$ & $0.041^{* * *}$ & $-0.005^{* * *}$ \\
ROA & $-0.057^{* *}$ & -0.014 & $-0.042^{* * *}$ \\
Tobin's Q & $-0.010^{* * *}$ & $0.017^{* * *}$ & -0.000 \\
Industry indicators & Yes & Yes & Yes \\
R-square & 0.126 & 0.189 & 0.084 \\
Sample size & 2720 & 2720 & 2720 \\
\hline
\end{tabular}

$*, * *, * * *$ indicates statistical significance at 15,10 and $5 \%$ levels

Table 4. Liquidity, debt and dividend structure. The table reports results of OLS regression of long-term debt, cash and equivalents and dividends, scaled by total assets on family indicator, return on assets, Everyday Price Index (EPI) and interest rate

\begin{tabular}{llll}
\hline & $\begin{array}{l}\text { Long term debt/ Total Assets } \\
(1)\end{array}$ & $\begin{array}{l}\text { Cash and Equivalents/Total Assets } \\
(2)\end{array}$ & $\begin{array}{l}\text { Dividends/ Total Assets } \\
(3)\end{array}$ \\
\hline Intercept & $0.170^{* * *}$ & 0.057 & -0.005 \\
Family Indicator & $-0.040^{* * *}$ & $0.052^{* * *}$ & $-0.006^{* * *}$ \\
ROA & $-0.097^{* * *}$ & $0.047^{* *}$ & $0.043^{* * *}$ \\
EPI & 0.000 & $0.001^{* * *}$ & $0.000^{* *}$ \\
Interest rate & 0.002 & $-0.009^{* * *}$ & $0.001^{* *}$ \\
R-square & 0.031 & 0.042 & 0.053 \\
Sample size & 2720 & 2720 & 2720 \\
\hline
\end{tabular}

$*, * *, * * *$ indicates statistical significance at 15,10 and $5 \%$ levels

\section{Conclusion and Summary of Results}

Agency theory establishes that conflicts can arise due to the divergent interests of managers and atomistic shareholders, the separation of ownership and control. Family firms present a special case of concentrated ownership, with extant research suggesting that family members having a presence in management while holding ownership shares mitigates these agency conflicts and results in an efficient, profitable ownership structure.

Our theoretical model was developed to determine the optimal time period over which net investment in a family firm is economically warranted and the types of investment that maximize the value of the firm. The goal of the empirical analysis was to test three corollaries of the model against non-family firms: Lower risk financial policy of maintaining relatively higher percentages of cash and lower dividends and long-term debt to total asset ratios. The statistical analysis shows that family-owned companies have less long-term debt and higher cash and equivalents. This result holds after we control for firm characteristics. Less debt and higher cash in family owned companies can be seen as evidence of better alignment of shareholder interests with management goals of increased share value through risk reduction.

This paper contributes to the body of work on family firms by providing additional evidence suggesting that the family ownership structure mitigates the agency conflicts that can arise when there is a separation of ownership and management. The results suggest that there is a link of managers' incentives with the incentives of owners with a more concentrated ownership stake and management structure.

The economic implications of the results suggest that the purpose of the higher precautionary cash balances, the policy of lower dividends and the policy of less reliance on long-term debt financing are the result of alignment of shareholders' interests with management goals of creating firm value through the mitigation of risk.

\section{Acknowledgement}

This paper benefited greatly from the comments of 2012 Eastern Finance Association and 2012 Eastern Economics Association session participants.

\section{Funding Information}

No external funding was provided for this manuscript.

\section{Author Contribution}

Elena Smirnova: Produced empirical part.

Sirousse Tabriztchi: Developed theoretical model.

Cary Lange: Collected data. 


\section{Ethics}

No ethical conflicts will arise after publication of the manuscript.

\section{References}

Anderson, R.C. and D.M. Reeb, 2003. Founding-family ownership and firm performance: Evidence from the S\&P 500. J. Finance, 58: 1301-1327. DOI: $10.1111 / 1540-6261.00567$

Baskin, J., 1987. Corporate liquidity in games of monopoly power. Rev. Econ. Statistics, 69: 312-319.

Belenzon, S. and R. Zarutskie, 2012. Married to the firm? Family Ownership, Performance and Financing in Private Firms, Duke University.

Brockman, P., X. Martin, D. Wang and S. Zhang, 2008. Family ownership and agency costs: Evidence from the valuation and level of cash holdings. University of Missouri at Columbia.

Brown, J.R. and B.C. Petersen, 2011. Cash holdings and R\&D smoothing. J. Corporate Finance, 17: 694-709. DOI: $10.1016 /$ j.jcorpfin.2010.01.003

Dybvig, P.H. and M. Warachka, 2010. Tobin's Q does not measure performance: Theory, empirics and alternative measures. SSRN Working Paper Series.

Demsetz, H. and K. Lehn, 1985. The structure of corporate ownership: Causes and consequences. J. Political Economy, 93: 1155-1177.

Easterbrook, F.H., 1984. Two agency-cost explanations of dividends. Am. Econ. Rev., 74: 650-659.

Fama, E.F. and M.C. Jensen, 1983. Separation of ownership and control. J. Law Econ., 26: 301-325.

Froot, K.A., 1993. Intel corporation, 1992.

Guney, Y., Aydin, O. and N. Ozkan, 2007. International evidence on the non-linear impact of leverage on corporate cash holdings. J. Multinational Financ. Manag., 17: 45-60.

DOI: $10.1016 /$ j.mulfin.2006.03.003

Jensen, M.C., 1986. Agency cost of free cash flow, corporate finance and takeovers. Am. Econ. Rev.

Jensen, M. and W. Meckling, 1976. Theory of the firm: Managerial behavior, agency costs and ownership structure. J. Financ. Econ., 3: 305-360. DOI: $10.1007 / 978-94-009-9257-3 \_8$

John, K., 1993. Managing financial distress and valuing distressed securities: A survey and a research agenda. Financ. Manage., 22: 60-78.

Kim, C.S., D.C. Mauer and A.E. Sherman, 1998. The0 determinants of corporate liquidity: Theory and evidence. J. Financ. Quantitative Analysis, 33: 335-359. DOI: $10.2307 / 2331099$
Martínez, J.I., B.S. Stöhr and B.F. Quiroga, 2007. Family ownership and firm performance: Evidence from public companies in Chile. Family Bus. Rev., 20: 83-94. DOI: 10.1111/j.1741-6248.2007.00087.x

Mikkelson, W.H. and M.M. Partch, 2003. Do persistent large cash reserves hinder performance? J. Financ. Quantitative Analysis, 38: 275-294. DOI: $10.2307 / 4126751$

Morck, R., Shleifer, A. and R. W. Vishny, 1988. Management ownership and market valuation: An empirical analysis. J. Financ. Econ., 20: 293-315.

Myers, S.C., 1977. Determinants of corporate borrowing. J. Financ. Econ., 5: 147-175. DOI: $10.1016 / 0304-405 X(77) 90015-0$

Myers, S.C., 1984. The capital structure puzzle. J. Finance, 39: 574-592. DOI: $10.1111 /$ j.1540-6261.1984.tb03646.x

Myers, S.C. and N.S. Majluf, 1984. Corporate financing and investment decisions when firms have information that investors do not have. J. Financ. Econ., 13: 187-221.

Myers, S.C. and R.G. Rajan, 1998. The paradox of liquidity. Q. J. Econ., 113: 733-771. DOI: $10.1162 / 003355398555739$

Opler, T., L. Pinkowitz, R. Stulz and R. Williamson, 1999. The determinants and implications of corporate cash holdings. J. Financ. Econ., 52: 3-46. DOI: 10.1016/S0304-405X(99)00003-3

Park, Y.K. and M. Son, 2009. Corporate governance and equity finance. Proceedings of the FMA Annual Meeting Program, pp: 21-24.

Shleifer, A. and R.W. Vishny, 1986. Large shareholders and corporate control. J. Political Economy, 94: 461-488.

Andrei, S. and R.W. Vishny, 1992. Liquidation values and debt capacity: A market equilibrium approach. J. Finance, 47: 1343-1366.

Stulz, R.M., 1990. Managerial discretion and optimal financing policies. J. Financ. Econ., 26: 3-27.

Villalonga, B. and R. Amit, 2006. How do family ownership, control and management affect firm value? J. Financ. Econ., 80: 385-417. DOI: 10.1016/j.jfineco.2004.12.005

Villalonga, B. and R. Amit, 2009. How are U.S. family firms controlled? Rev. Financ. Stud., 22: 3047-3091. DOI: $10.1093 / \mathrm{rfs} / \mathrm{hhn} 080$

Whited, T.M., 1992. Debt, liquidity constraints and corporate investment: Evidence from panel data. J. Finance, 47: 1425-1460. DOI: $10.1111 /$ j.1540-6261.1992.tb04664.x 